BARrio Gallardo, A., «El régimen de la vivienda familiar: un estudio del art. I9o del Código del Derecho foral de Aragón», REDUR I5, diciembre 20I7, págs. 7-28. ISSN I695-078X

\title{
EL RÉGIMEN DE LA VIVIENDA FAMILIAR: UN ESTUDIO DEL ART. I9O DEL CÓDIGO DEL DERECHO FORAL DE ARAGÓN
}

\author{
Aurelio BARRIO GALLARDO \\ PROFESOR CONTRATAdo DOCTOR DE DERECHO CIVIL \\ UNIVERSIDAD DE ZARAGOZA
}

Sumario: I. Introducción. I.I. Finalidad del precepto. I.2. Títulos de ocupación de la vivienda. I.3. El mobiliario ordinario de la vivienda. II. El régimen del art. I90.I CDFA. II.I. Actos de disposición. II.I.I. Disposición inter vivos. II.I.2. Derecho de viudedad. II.I.3. Disposición mortis causa. II.2. El derecho objeto de disposición. II.2.I. Actos de disposición. II.2.2. Actos de gravamen. II.3. Consentimientos previos y renuncias anticipadas. III. Régimen de impugnación de los actos. III.I. Invalidez del acto de disposición. III.2. Plazo y legitimación. IV. Protección de terceros. IV.I. Crítica general del precepto. IV.2. El art. I90.3 CDFA y la protección registral. IV.3. Pervivencia del derecho expectante. IV.4. La disposición del mobiliario y los terceros. V. Bibliografía.

RESUMEN: La vivienda familiar constituye el bien más preciado de cualquier economía doméstica. Semejante relevancia unida al hecho de ser el lugar donde discurre la vida en pareja y se cumplen los deberes tanto conyugales como paterno-filiales justifica la especial protección que le dispensa el legislador constante el matrimonio y aún después. Tal norma se encuentra presente en la mayoría de los Derechos civiles que coexisten en España. En este trabajo se realiza un análisis sistemático y pormenorizado del art. I९० del Decreto Legislativo I/20II, de 22 de marzo, por el que se aprueba el «Código del Derecho Foral de Aragón».

PAlabras Clave: vivienda familiar, derecho aragonés, disposición y gravamen, asentimiento, impugnación judicial, anulabilidad, protección del tráfico

ABSTRACT: Family dwelling is the most precious asset of any household. This relevance, together with the fact that home is where couple life goes by and duties both conjugal and paternal-filial are fulfilled, justifies the special protection dispensed by lawmaker while marriage lasts and even after. This rule is present in most of the civil laws coexisting in Spain. This paper offers a systematic and detailed analysis of section I9O of Legislative Decree I/20II, of 22 March, which approves the «Code of Aragonese Regional Law».

KEYwORDS: family dwelling, aragonese law, disposal and burden, approval, court challenge, voidability, protection of legal transactions. 


\section{Introducción}

\section{I.I. Finalidad del precepto}

El art. I90.I CDFA traduce al sistema foral aragonés una disposición protectora de la vivienda familiar que se enmarca en línea de continuidad con la reforma de la Ley II/I98 $\mathrm{I}^{\mathrm{I}} \mathrm{y}$, desde entonces, se halla presente en todos los Derechos civiles españoles con la única salvedad del Derecho balear². Conocía un precedente en el art. 5I Comp. ${ }^{3}$, a cuyo tenor se decía: «corresponde a cada cónyuge la administración y disposición de sus propios bienes. Pero necesitará el consentimiento del otro o, en su defecto, autorización judicial, para disponer de los derechos sobre la vivienda habitual o el mobiliario ordinario de la misma, o para sustraerlos al uso común».

Pero una vez incorporada la separación de bienes como régimen optativo o convencional se hizo preciso elevarla a rango de disposición general, que hoy acoge el citado art. I90.I CDFA: «para realizar actos de disposición voluntaria de los derechos que a uno de los cónyuges correspondan sobre la vivienda habitual de la familia o el mobiliario ordinario de la misma, así como para sustraerlos al uso común, será necesario el consentimiento del otro o, en su defecto, autorización judicial. En ambos casos, con la enajenación se extingue el derecho expectante de viudedad».

Dicha regla suele incardinarse, en tanto que soporte físico de la comunidad de vida, con los deberes conyugales de ayuda y socorro mutuos, y el de vivir juntos. En su virtud se protege inmediatamente al cónyuge no titular y mediatamente al resto de la familia ${ }^{4}$ no sin una cierta desconfianza hacia un miembro de la unión matrimonial: el titular del uso que se presume cedido en beneficio del grupo en aras de su contribución a las incumbencias comunes (art. I87.I CDFA). La vivienda es así un bien cuyo uso queda al servicio del grupo o ente pluripersonal que en ella se asienta quien quiera que sea su propietario (STS 3I diciembre I994 [RJ I0330]). Con tal norma se pretende «salvar el alojamiento del matrimonio — de la familia - y los muebles que lo guarnecen de la arbitrariedad o mala voluntad del cónyuge que puede disponer de ellos (...)» e impide «que un cónyuge pueda, por sí, dejar al otro en la calle o en una casa vacía, sin amueblar» ${ }^{5}$.

\footnotetext{
${ }^{1}$ SÁnchez Rubio, A., «Régimen jurídico de la vivienda familiar en Aragón», Actas de los Cuartos Encuentros del Foro de Derecho Aragonés, Zaragoza, El Justicia de Aragón, I995, pág. 54. Traída del sistema matrimonial franco-belga (vid. sobre este extremo y, con carácter general, GARCÍA CANTERO, G., «El régimen matrimonial primario y su marco en el Código civil», RJIB, n. ${ }^{\circ}$ I4, 20I6, págs. II-I2). Para los antecedentes legislativos y tramitación parlamentaria de la norma foral, vid. ForCADA MiRANDA, F.J., «La vivienda familiar en las situaciones de ruptura matrimonial», Actas de los Decimocuartos Encuentros del Foro de Derecho Aragonés, Zaragoza, El Justicia de Aragón, 2005, págs. I7 y ss.

2 Vid. STSJ Baleares 3 septiembre I998 (Roj: STSJ BAL 778/1998).

${ }^{3}$ Cfr. sobre él, Rams Albesa, J., «Comentario de los arts. 4I a 59 de la Compilación (Pasivo, gestión, disolución, liquidación y división de la comunidad conyugal legal)», Comentarios a la Compilación del Derecho civil de Aragón (dir. J. Delgado), vol. II, Zaragoza, DGA, I993, pág. 264.

${ }^{4}$ De los Mozos, J.L., Comentarios al Código Civil y Compilaciones Forales, t. XVIII, vol. I , Artículos 1315 a 1343 del Código Civil, Madrid, Edersa, I982, págs. I26-127.

${ }^{5}$ Es una opinión doctrinal generalizada, LaCruz Berdejo, J.L., Derecho de Familia, Fasc. $1^{\circ}, 2^{\circ}$ y $3^{\circ}$, edición experimental, Bosch, Barcelona, I982, pág. 299; DE Los Mozos, J.L., Comentarios, I982, op. cit., pág. I3I; RAMS Albesa, J., Elementos de Derecho civil, t. IV. Derecho de familia, Madrid, Dykinson, 2010, pág. I28; Moralejo Imbernón, N., «Artículo I320», Comentarios al Código Civil (dir. R. Bercovitz), t. VII. Arts. 1265 a 1484, Valencia,
} 


\section{I.2. Títulos de ocupación de la vivienda}

El precepto se refiere a la disposición de los derechos que a uno solo de los cónyuges correspondan sobre la vivienda o su mobiliario, al igual que hacía el art. 5I Comp.; excluye, por tanto, los actos de codisposición que siguen un régimen diferente (arts. $235 \mathrm{y}$ ss. CDFA). El artículo veda aquellos actos que entrañen sustraer la vivienda o su mobiliario del uso común, fórmula que acoge la tesis predominante en la doctrina ${ }^{6}$ y que con gran tino da la pauta del recto actuar y se orienta a evitar «el ejercicio de todo derecho que suponga atentar, bajo cualquier forma, el pacífico goce de su alojamiento por la familia». En palabras del Tribunal Supremo queda proscrito «realizar cualquier acto que genere la pérdida del derecho a ocupar la vivienda» (STS 3I diciembre I994 [Roj: STS 2023I/I994]).

Es indiferente, entonces, por qué título, real u obligacional, se ocupe la vivienda: la disposición unilateral de tales derechos en modo que su uso quede sustraído al destino familiar requerirá del asentimiento uxoris. Ya se interpretaba así el antiguo art. $6_{5}$ CC, en relación al consentimiento que pedía el derogado art. I4I3 CC (STS II octubre I979) [RJ 3387]). Tras I98I el sentido del I320 CC es similar: «el citado artículo habla de "disponer de los derechos sobre la vivienda", por lo que tales derechos pueden ser tanto de carácter real como personal, y en consecuencia los cónyuges tendrán que actuar de consuno para enajenar la propiedad, extinguir el usufructo o cualquier derecho, en virtud del cual se habite la finca y no pueda continuarse la habitación; no cabe renunciar al arrendamiento» (STS 3I diciembre I994 [Roj: STS 2023I/I994]).

Las posibilidades son tantas como quepa imaginar (propiedad, usufructo, alquiler, uso, habitación...); pienso que quizá existan mayores dudas respecto al precario ${ }^{9}$ en tanto que título inidóneo para conferir un derecho de ocupación con cierta vocación de permanencia. «Si el piso fue ocupado por mera tolerancia del comunero y no nació ningún derecho, no existe acto de disposición a que el art. I320 se refiere». La ocupación no generaba ningún derecho a permanecer en la vivienda (cfr. STS 2I mayo I990 [RJ 3827]). En mi opinión, una cuestión es que el precarista quede a merced del titular del derecho

Tirant lo Blanch, 20I3, pág. 9327, acogida después por la doctrina registral (RDGRN 6 marzo 2004 [RJ 2474]) y extensible al Derecho aragonés (vid. Martínez CorTes, J., Actas, op. cit., pág. I33).

${ }^{6}$ LACruZ, J.L., Derecho de familia, op. cit., pág. 300; De los Mozos, J.L., Comentarios, I982, op. cit., pág. I29; RodríGuez LóPEZ, F., «Notas sobre la vivienda habitual de la familia (en turno de rectificación)», RCDI, I993, pág. I6o9; AMUNÁtegui RodRígueZ, C., «La libertad de pacto en el régimen de separación de bienes», Autonomía de la voluntad y negocios jurídicos de la familia (coord. J. RAMS), Madrid, Dykinson, 20Io, pág. I82; Barrio Gallardo, A., «La autonomía privada y el art. I320 del Código civil», $A D C$, 20I2, n. 4, pág. I663. Para Aragón, MARTínez Cortés, J., «El régimen económico matrimonial de separación de bienes», Actas de los Decimoterceros Encuentros del Foro de Derecho Aragonés, Zaragoza, El Justicia de Aragón, 2004, pág. I33.

Herrero García, cit. por Martínez de Aguirre Aldaz, C. (coord.), Curso de Derecho Civil (IV), Derecho de Familia, Madrid, Edisofer, 2016, pág. 234.

${ }^{8}$ El titular no puede extinguir unilateralmente el arrendamiento que permite el uso de la vivienda familiar (STS 3I diciembre I994 [Roj: STS 2023I/I994]); cualquier causa judicial que pueda deparar el fin del inquilinato, exige demandar al consorte, siendo un supuesto de litisconsorcio pasivo necesario (STC 3I octubre I986 [RTC I35]).

${ }^{9}$ Lo admite DE Los Mozos, J.L., Comentarios, I982, op. cit., pág. I29; lo da por supuesto y exige permiso para renunciar a mantener la situación de precario, SÁnchez Rubio, A., Actas, op. cit., pág. Go. Vid. también Martínez Cortes, J., Actas, op. cit., pág. I28 y Merino Hernández, J.L., (dir.). Memento Experto. Derecho Foral de Aragón, Francis Lefebvre, 20II, pág. I8I. 
sobre la vivienda, y pueda ser desalojado en cualquier momento, y otro que el mismo precarista decida abandonar el inmueble, en este último caso, la decisión debería ser tomada entre ambos cónyuges.

\section{I.3. El mobiliario ordinario de la vivienda}

En el art. I90.I CDFA, a efectos de prestar el debido asentimiento, se incluye no sólo la vivienda habitual, sino además «el mobiliario ordinario de la misma»; expresión ya contenida en el art. 5I Comp. y que se tenía por sinónima de menaje o mobiliario doméstico $^{\mathrm{IO}}$, es decir, muebles de amueblamiento cuya finalidad es alhajar las habitaciones ${ }^{\mathrm{II}}$. Parece que el ámbito de aplicación de la norma foral es más limitado que el del art. I320 CC, en cuyo tenor se puede discutir si la alusión a «muebles de uso ordinario de la familia» se refiere a todos los bienes muebles, p. ej. un automóvil, o tan sólo a los de amueblamiento. Es prevalente de nuevo la postura de LACRUZ, para quien la expresión debe identificarse con mobiliario o ajuar familiar; resulta decisivo en esta interpretación el argumento que proporciona el art. $346 \mathrm{CC}^{\mathrm{I2}}$.

Por coherencia sistemática, podría pensarse también en las «ropas, el mobiliario y enseres que constituyen el ajuar de la vivienda habitual común de los esposos», que menciona el precepto consecutivo (art. I32I CC). Sin embargo, el mobiliario ordinario no se limita solamente al ajuar, sino que incluye también los muebles de uso común y comprende en su objeto los enseres esenciales al buen funcionamiento del hogar que se hallen en el interior de la vivienda ${ }^{\mathrm{r}}$. Si no se encuentran en ella, sino en el apartamento vacacional o despacho profesional de uno de los cónyuges, tampoco se aplica el art. I90 $\mathrm{CDFA}^{\mathrm{I}}$, al igual que si se produce su sustitución por otros equivalentes destinados a función análoga. En tal supuesto no parece necesario el asentimiento ${ }^{15}$.

El mobiliario al que alude el art. I90.I CDFA sería el destinado al empleo conjunto de todo el grupo social y, por tanto, de uso indistinto por cualquier miembro de la familia ${ }^{\mathrm{r} 6}$. No abarcaría, aunque se encontraran en ella, los enseres dedicados al ejercicio de la profesión, arte u oficio de uno de los cónyuges u otros de uso exclusivo o personalísimo ${ }^{\mathrm{T}}$.

\footnotetext{
${ }^{\text {Io }}$ LAtorre Martínez de BARojA, E., «Disposiciones generales», Manual de Derecho matrimonial aragonés, Zaragoza, Los Fueros, 2007, pág. 36.

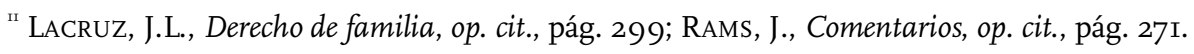

${ }^{12}$ LACRUZ, J.L., Derecho de familia, I982, op. cit., pág. 299; HerRero lo identifica con mobiliario o ajuar familiar con argumento ex art. 346.2. ${ }^{a} \mathrm{CC}$.

${ }^{13}$ De los Mozos, J.L., Comentarios, I982, op. cit. pág. I30; BANDrés SÁnCheZ-CruZAT, J.M. y R.M., «Gestión de los bienes privativos. Art. 5I». Comentarios al Código Civil $y$ Compilaciones Forales, t. XXXIII, vol. $2^{\circ}$. Artículos 48 a 88 de la Compilación de Aragón, Madrid, Edersa, I990, pág. 50.

${ }^{14}$ Vid. De Los Mozos, J.L., Comentarios, I982, op. cit., pág. I30.

${ }^{15}$ Martínez de Aguirre, C., Curso, 20i6, op. cit., pág. 233.

${ }^{16}$ Herrero García, M.J., «Del régimen económico del matrimonio. Disposiciones Generales», Comentario del Código Civil, t. II, Madrid, Ministerio de Justicia, pág. 589; Latorre MarTínez DE BARojA, E., Manual, 2007, op. cit., pág. 36.

${ }^{17}$ Latorre Martínez de BARojA, E., Manual, 2007, op. cit., pág. 36; Costas RodAL, L., «Del régimen económico matrimonial. Disposiciones generales», Comentarios al Código civil (coord. R. Bercovitz), Cizur Menor (Navarra), Thomson Reuters-Aranzadi, 2009, pág. 1567.
} 
Resulta evidente que tampoco las joyas, alhajas, objetos preciosos, cuadros y otros de un valor extraordinario se ven comprendidos dentro del «mobiliario» como entiende pacíficamente doctrina ${ }^{\mathrm{r} 8}$.

\section{El régimen del artículo I90.I CDFA}

\section{II.I. Actos de disposición}

\section{II.I.I. Disposición inter vivos}

El consentimiento, si la vivienda fuera común, o asentimiento ${ }^{\text {t9 }}$ si es privativa, bajo el consorcio conyugal, o propia, en separación de bienes, se requiere para los actos de disposición voluntaria (art. I90.I CDFA); a contrario, no lo precisan en general los actos procesales tanto de jurisdicción voluntaria como contenciosa ${ }^{20}$. «La norma aclara ya su limitación a actos de disposición "voluntaria" (expresión que no aparecía en el art. 5I de la Compilación), con exclusión de los casos de enajenación o ejecución forzosa» ${ }^{2 \mathrm{~T}}$. Nada impide así que la enajenación sea forzosa y se deba a un proceso judicial seguido para depurar la responsabilidad ex art. I9II CC y las deudas contraídas unilateralmente, sean privativas o consorciales, terminen por alcanzar la vivienda familiar.

No habría inconveniente constitucional en declarar inembargable la vivienda familiar $^{22}$, pero de momento dicho bien no se incluye en el elenco de los arts. 605 y 606 LEC. La única excepción que cabría señalar pasaría por que uno de los cónyuges se haya constituido en emprendedor de responsabilidad limitada (art. 8 LAEI ${ }^{23}$. Fuera de este caso, bastará la notificación al consorte para que el embargo pueda anotarse (art. I44.5 RH) ${ }^{24}$ y no cabrá apreciar arbitrariedad o mala voluntad puesto que la realización en pública subasta de este bien, tan preciado para las economías domésticas ${ }^{25}$, se habrá producido muy a pesar de

${ }^{18}$ LaCruZ, J.L., Elementos, op. cit., pág. 204; DE los Mozos, J.L., Comentarios, I982, op. cit., pág. I30; Albaladejo, M., Curso de Derecho Civil, t. IV, Barcelona, Bosch, I997, pág. I57; Herrero García, M.J., Comentarios, t. II, op. cit. pág. 589.

19 «El consentimiento del esposo no dueño para vender o disponer de otro modo constituye un asentimiento cuando el cónyuge no es cotitular del bien que intenta enajenar, y en tal caso el que asiente no es parte del acto de disposición» (LACRUZ, J.L., Derecho de familia, op. cit., pág. 30I). Vid. también, De la CÁmARA ÁlVAREZ, M., «El nuevo artículo I4I3 del Código Civil», ADC, vol. XII, n. ${ }^{2}$ 2, I959, pág. 45I; CANO TELLO, C.A., La nueva regulación de la sociedad de gananciales, Madrid, Cuadernos Civitas, I98I, pág. 4I; García CANTERo, G., «Notas sobre el régimen matrimonial primario», DJ, ene-dic. I982, pág. 309: MORALEJO IMBERNóN, N., «Artículo I320», op. cit., pág. 933I; en Aragón, BANDrés SÁnCHEZ-CruZAT, J.M. y R.M., Comentarios, I990, op. cit., pág. 47; RAMS AlbESA, J., Comentarios, op. cit., pág. 272; MARTínez CoRTES, J., Actas, op. cit., pág. I33.

${ }^{20}$ LACRUZ, J.L., Derecho de familia, op. cit., pág. 30I; RAMS, J., Elementos, op. cit. pág. I30.

${ }^{2 \pi}$ Forcada Miranda, F.J., Actas, op. cit., pág. 2I; LACRUZ, J.L., Derecho de familia, op. cit., pág. 3O2; SÁnCHEZRubio, A., Actas, op. cit. págs. 58-59; Rams, J., Elementos, op. cit., pág. I3I; Serrano GarCía, J.A., Manual, op. cit., pág. 299.

${ }^{22}$ Así lo entiende, ORTEGA y DíAZ-AmBRonA, J.O., «Constitución y derecho constitucional», El hogar y el ajuar de la familia en las crisis matrimoniales: bases conceptuales y criterios judiciales (dir. P.J. VILADRICH), Pamplona, Eunsa, i986, pág. 55 .

${ }^{23}$ Ley i4/2013, de 27 de septiembre, de apoyo a los emprendedores y su internacionalización (BOE núm. 233, 28 septiembre 2013 , págs. $78787-78882$ ), aplicable en virtud de su art. 2.

${ }^{24}$ Vid. STS I8 febrero I995 (RJ 88I). 
su titular.

\section{II.I.2. Derecho de viudedad}

Resta ver qué sucede con el derecho de viudedad que permanecía expectante sobre la vivienda a la espera de materializarse como usufructo en caso de fallecer en primer término el cónyuge titular. La existencia de este derecho foral, frente al régimen del CC, llevaba a parte de los autores a entender menos necesaria una norma como el art. I90 CDFA en Aragón ${ }^{26}$. El expectante se extingue — dice el precepto- «en ambos casos», es decir, en la disposición voluntaria si cuenta con la anuencia del consorte o, en su defecto, con la oportuna licencia judicial (art. I90.I i.f. CDFA).

Tal asentimiento uxorio puede ser expreso pero también tácito (STS ig octubre I994 [RJ 8I20]). La mera presencia en la notaría del cónyuge, acompañando a su consorte, probada después mediante declaración testifical del oficial es suficiente para dar cumplimiento al art. I320 CC y, por extensión, a otras normas análogas (SAP Santa Cruz de Tenerife I2 mayo 2003 [JUR 2003\239932]). El mismo efecto podría surtir acompañar al titular en las gestiones preliminares (enseñar el piso, discutir el precio...) o fijar un cartel con el anuncio de venta en el portal de la finca (SAP Bilbao 2I septiembre I99I [RGD, $573 /$ I992] $)^{27}$.

Además, si la declaración de voluntad del cónyuge extingue el derecho, la supletoria del juez, que la sustituye, debe producir idéntico resultado ${ }^{28}$. Se pone fin al absurdo que conllevaba la conservación del expectante cuando el órgano jurisdiccional había autorizado la venta del inmueble; ningún postor tenía interés entonces en adquirir la vivienda, si bien la eventual existencia del gravamen debía tenerse en cuenta al efectuar la tasación. CALATAYUD SIERRA entiende que el art. I90.I in fine CDFA es una norma de pleno sentido común, frente al art. 5I Comp., que no mencionaba expresamente esta consecuencia; ante tal silencio, la doctrina se mostraba favorable a la subsistencia del gravamen que entraña la viudedad a pesar del sentido del auto judicial ${ }^{29}$ dificultando la existencia de postores en la subasta.

Cuando la enajenación judicial de la vivienda se produzca a consecuencia de la responsabilidad patrimonial universal del deudor (art. I9II CC), se habrá de estar al art. 28I CDFA y, en general, a la naturaleza de la deuda contraída, que como bien apunta LERMA RODRIGO, rara vez se evidencia en el curso del proceso, sobre todo si es de ejecución forzosa $^{30}$. El expectante se extinguirá en la gran mayoría de las ocasiones, vigente el

\footnotetext{
${ }^{25}$ «Se toma el dato de que, en un porcentaje verdaderamente abrumador, el único bien de valor de titularidad privativa o común suele ser la vivienda que habitan» los cónyuges (RAMS, J., Comentarios, op. cit., págs. 275-276).

${ }^{26}$ Vid. Latorre Martínez de Baroja, E., Manual, op. cit., pág. 35; insiste de nuevo en pág. 36.

${ }^{27}$ Cfr. Belda SÁenz, M.C., «Notas para un estudio del artículo I320 del Código civil español», RDP, abr. I985, pág. 342.

${ }^{28}$ Serrano García, J.A., Manual, op. cit., pág. 299; BAyod LóPez, C., Manual, op. cit., pág. 477.

${ }^{29}$ Sancho Rebullida, F. y De Pablo, P., Comentarios a la Compilación del Derecho civil de Aragón (dir. J. Delgado), Zaragoza, DGA, págs. 745-746 y RAMS, J., Comentarios, I993, op. cit., págs. 271-272.

${ }^{30}$ Lerma Rodrigo, C., «El derecho expectante de viudedad», Actas de los Decimocuartos Encuentros del Foro de Derecho Aragonés, Zaragoza, El Justicia de Aragón, 2005, pág. I52.
} 
consorcio conyugal, aunque puede pervivir de modo residual en las deudas privativas contraídas constante matrimonio por uno solo de los cónyuges (art. 28I.I CDFA).

En separación de bienes subsistirá, salvo en la hipótesis de los arts. I87 y i89 CDFA (art. 28I.2 CDFA), y podría dificultar el buen fin de la subasta cuando al notificarse el embargo al cónyuge del titular manifieste su voluntad de conservarlo. Quedaría reproducida esta misma doctrina con ocasión de las ejecuciones hipotecarias para el caso de que el titular declarara que el inmueble no constituía la vivienda familiar (art. I90.3 CDFA) y se hubiera llegado a inscribir dicho gravamen real en el Registro.

\section{II.I.3. Disposición mortis causa}

Guarda silencio el precepto, al igual que el art. I320 CC, pero es un parecer muy extendido entre los autores que el art. I90.I CDFA se refiere a los actos realizados inter vivos y no a las disposiciones mortis causa; se señala que con la muerte del titular cesa el carácter familiar de la vivienda ${ }^{31}$. Podría pensarse, sin embargo, que la situación que la norma trata de evitar cabe que se dé por igual en algún caso con ocasión del fallecimiento. En Aragón es posible, incluso, que el cónyuge del titular haya tomado parte en ellos, p. ej. testamento mancomunado o pacto sucesorio, y se sepa ya destinario de la vivienda. No obstante, la ambulatoriedad de las atribuciones por causa de muerte lleva a que el acto dispositivo sólo despliegue eficacia una vez fallecido el titular — con excepción de algunos pactos sucesorios (arts. 389 y ss. CDFA) - y, entre tanto, han podido sobrevenir circunstancias que alteren ese destino inicial del bien (p. ej. causas de indignidad, revocación del testamento...)

Si la vivienda se ocupa en virtud de un arrendamiento, el supérstite podría subrogarse en el inquilinato (art. I6.I a) LAU) y, en cualquier caso, frente a la incertidumbre de la legítima del CC, le asistirá la viudedad foral (arts. I92, 27I y ss. CDFA) y sobre el mobiliario ordinario, las aventajas (art. 266.2 CDFA). Otro motivo para excluir la disposición por causa de muerte es que la enajenación con reserva de usufructo, derecho real de ordinario vitalicio, suele entenderse permitida sin precisar el concurso o aprobación del consorte ex art. I90.I CDFA, sabiendo que una vez fallecido el usufructuario se extinguirá (arts. 5I3.I CC); de ahí no la necesidad, pero sí la conveniencia de constituirlo, además, en beneficio del resto de miembros de la familia ${ }^{32}$.

\section{II.2. El derecho objeto de disposición}

II.2.I. Actos de disposición

Conocido el espíritu de la norma - preservar el uso de la vivienda en beneficio del conjunto de este grupo social— los autores se afanan en discernir si es preciso o no recabar

\footnotetext{
${ }^{31}$ LaCruZ, J.L., Derecho de familia, op. cit., pág. 30I; Rebolledo VArela, A.L., «La vivienda familiar y la Ley de Arrendamientos Urbanos», La Ley, I984, n. 2, pág. 504; Albaladejo, M., Curso, op. cit., pág. I57; MARTíneZ DE Aguirre, C., Curso, op. cit., pág. 234; Latorre Martínez de Baroja, E., Manual, op. cit., pág. 38; en contra, «parece posible el consentimiento para acto mortis causa» (RAMS, J., Elementos, op. cit., pág. I30). Vid. STS 26 abril I995 (Roj: STS 2351/I995).

${ }^{32}$ No siempre se menciona, por todos los expositores, y lo recuerda LACRUZ: «si se hace con reserva de usufructo en provecho del cónyuge supérstite y de la familia entonces conviviente» (LACRUZ, J.L., Derecho de familia, I982, op. cit. pág. 300).
} 
el beneplácito del consorte o, en su caso, la autorización judicial supletoria en las más diversas hipótesis de actos dispositivos. Siendo el art. I90.I CDFA una norma prohibitiva, merece una interpretación en sus justos y más estrictos términos (favorabilia amplianda, odiosa restringenda) ${ }^{33}$. No se albergan dudas en aplicar el art. I90.I CDFA a la transmisión del dominio o, en general, del derecho que permite la ocupación y el disfrute, p. ej. vender la propiedad, ceder dicho contrato, renunciar al usufructo (art. 513.4. ${ }^{a} \mathrm{CC}$ ).

Pienso, sin embargo, que la permuta por otra vivienda de mejores o similares características (prestaciones, situación...) habría de quedar exenta aunque podría suponer un traslado de domicilio (art. I84.I CDFA). En este último supuesto no sería ya preciso declarar que el inmueble adquirido constituye la vivienda familiar (RDGRN 27 mayo 2015 [RJ 3026]). En caso de venta, con automática sustitución en idéntico escenario, bien podría aplicarse la misma regla. P. ej. no se vería incluido el supuesto de la enajenación de la vivienda para adquirir, en forma simultánea, otra más capaz, mejor situada o más conveniente desde cualquier punto de vista ${ }^{34}$.

La disposición, si es con reserva de usufructo, suele ser tolerada por los autores ${ }^{35}$ en tanto permite a la familia seguir residiendo en el inmueble ${ }^{36}$; en verdad, habría de examinarse cuál es su plazo de duración (art. 513.2 CC). P. ej. la reserva de un usufructo a favor del enajenante, constituido en atención a que sus hijos, siendo menores, alcancen la edad de 80 años o término semejante ex art. 5I6 CC parece razonable que no requiera de asentimiento alguno. Los derechos de uso y habitación no son transmisibles (art. 525 CC) aunque se debe estar a lo dispuesto en el título de constitución (art. 523 CC).

Ya se es menos complaciente si se vende para continuar como arrendatario por su exposición al desahucio ${ }^{37}$, tesis revitalizada tras la última reforma de la LAU, que empeora notablemente la posición del inquilino ${ }^{38}$. En el supuesto del arrendamiento de vivienda, cuando el inquilino sea uno solo de los cónyuges, debe operar por igual la protección del uso de la vivienda familiar en caso de desistimiento o renuncia. Pero habrá de sujetarse al art. I2 $\mathrm{LAU}^{39}$, que debe prevalecer sobre el art. $1320 \mathrm{CC}$, en tanto que Ley especial y, sobre

\footnotetext{
${ }^{33}$ Como la norma es limitativa hay que interpretarla en sentido restrictivo. Vid. De LOS Mozos, J.L., Comentarios, op. cit., pág. I29; SÁnCHEZ Rubio, A., Actas, op. cit., págs. 57 y 60, así también, STS 8 junio I993 (Roj: STS I7762/1993).

${ }^{34}$ En el mismo sentido, De los Mozos, J.L., Comentarios, I982, op. cit., págs. I29-I30.

${ }^{35}$ En contra, Herrero García, M.J., Ministerio, t. II, op. cit. pág. 590; Espiau Espiau, S., La vivienda familiar, PPU, Barcelona, I992, pág. I44.

${ }^{36}$ LaCruZ, J.L., Derecho de familia, I982, op. cit., pág. 300; DE Los Mozos, J.L., Comentarios, I982, op. cit. pág. i29; Albaladejo, M., Curso, I997, op. cit. pág. i57; RAms, J., Comentarios, i993, op. cit., pág. 27i; SÁnChEZ Rubio, A., Actas, op. cit., pág. 58; MARTínez de Aguirre, C., Curso, 20i6, op. cit., pág. 234; PeÑA Bernaldo de Quirós, M., Derecho de Familia, Universidad Complutense de Madrid, Sección de Publicaciones, I989, pág. I7I; ForCADA Miranda, F.J., Actas, op. cit., pág. I8.

${ }^{37}$ GimÉnEz DuART, T., «Cargas y obligaciones del matrimonio», RDP, I982, pág. 542; RodríGuEZ LóPEZ, F., «Notas sobre la vivienda...», loc. cit., pág. I399; DE LOS Mozos, J.L., Comentarios, I982, op. cit. pág. I29; SÁNCHEZ Rubio, A., Actas, op. cit., pág. 58.

${ }^{38}$ Vid. con carácter general, PARRA LuCÁN, M.A., «El contrato de arrendamiento de vivienda: desde la salvaguardia de los derechos del arrendatario a su desprotección», Cuadernos de Aranzadi Civil-Mercantil, Thomson-Aranzadi, El Cano (Navarra), 20I4.

${ }^{39}$ Cfr. Sánchez Rubio, A., Actas, op. cit., pág. 57; Martínez Aguirre, C., Curso, op. cit. pág. 207; ForCAdA MirandA, F.J., Actas, op. cit., pág. I8.
} 
todo, norma posterior a la del Código Civil.

Este argumento no es, sin embargo, definitivo para el Derecho aragonés cuyo art. I90 CDFA, que trae causa del art. 8 de la derogada Ley 2/2003, de I2 de febrero, de régimen económico matrimonial y viudedad (Lrem) es posterior a la LAU; cabe discutir si prevalece sobre ella en virtud de un título competencial. Lo más probable es que la regulación contenida en la LAU esté dictada al amparo del art. I49.I.I. ${ }^{a} \mathrm{CE}$ y, por ende, sea de aplicación directa su art. I2 en detrimento de la norma aragonesa ${ }^{40}$.

Igualmente resulta discutible si el arrendatario puede subarrendar (p. ej. alquilar una o varias habitaciones a un tercero) en la medida que el acto constituye una sustracción no total, sino tan solo parcial de la vivienda en detrimento de su uso por la familia. En tal caso la oposición doctrinal estriba más en salvaguardar la intimidad del hogar ${ }^{4 \mathrm{~T}}$ que propiamente en la pérdida del uso del inmueble como morada. En contra, sostiene LACRUZ que «en virtud del "derecho al hogar", el cónyuge dueño del inmueble destinado a habitación familiar no podrá arrendarlo sin consentimiento de su consorte (...). Podrá, a lo más, arrendar parcialmente aquellas habitaciones que no se utilicen por la familia» ${ }^{42}$.

\section{II.2.2. Actos de gravamen}

Por último, resta el estudio de los actos no de enajenación, sino de gravamen, sobre los que nada decía el art. 5I Comp. y tampoco se pronuncia el art. I320 CC. La expresión «actos de disposición voluntaria» se suele dar como comprensiva de ambas clases de actos, esto es, de enajenación y de gravamen ${ }^{43}$. La constitución de un usufructo, conservando el cónyuge la nuda propiedad, implica una pérdida inmediata del uso habitacional y cae, por tanto, en el régimen del art. I90.I CDFA. Lo mismo sucede con el uso y la habitación ${ }^{44}$ y deviene extensivo al arrendamiento.

Sin duda, el caso que suscita mayor controversia es la hipoteca, que no conlleva desplazamiento posesorio, pero puede dar como resultado la pérdida de la vivienda, que en principio tampoco se halla protegida por la viudedad, caso de realizarse la garantía tras un proceso de ejecución forzosa. Esa eventual puesta en peligro del alojamiento familiar hace que en la práctica suela exigirse la prestación de dicha autorización ${ }^{45}$, a veces con apoyo en el art. $138 \mathrm{LH}^{46} \mathrm{y}$, por inercia, la renuncia expresa y formal al derecho expectante de

\footnotetext{
${ }^{40}$ Vid. PARRA LuCÁN, M.A., «El contrato de arrendamiento de vivienda», op. cit., pág. II7.

${ }^{4 \mathrm{I}}$ Rams Albesa, cit. Sánchez Rubio, A., Actas, op. cit., pág. 58.

${ }^{42}$ LACRUZ, J.L., Derecho de familia, I982, op. cit., pág. 300.

${ }^{43}$ Vid., por todos, Forcada Miranda, F.J., Actas, op. cit., págs. I8 y 22; antes de la Lrem, Rams, J., Comentarios, op. cit., pág. 273.

${ }^{44}$ RAms, J., Comentarios, op. cit., pág. 273; RAMS, J., Elementos, 20I0, op. cit., pág. I29.

${ }^{45}$ De los Mozos, J.L., Comentarios, I982, op. cit. pág. I29; Albaladejo, M., Curso, I997, op. cit., pág. I57; Rams, J., Comentarios, I993, op. cit., pág. 269; SÁnChEZ Rubio, A., Actas, op. cit., pág. 59; Lerma Rodrigo, C., Actas, op. cit., pág. I50; MARTínEZ CorTES, J., Actas, op. cit., pág. I33; ForCAdA MirAndA, F.J., Actas, op. cit., pág. 22.

${ }^{46}$ Así, p. ej. Martínez de Aguirre, C., Curso, 20i6, op. cit. pág. 234; SánChez Rubio, A., Actas, op. cit., pág. 59; SÁnCHEZ-Rubio ha cuestionado con buenos argumentos que la anuencia del consorte pudiera devenir innecesaria (vid. SÁnchez Rubio, A., Actas, op. cit., págs. 59-60).
} 
viudedad ${ }^{47}$. Según tiene declarado el TS, «el consentimiento se exige para aquellos casos en que el acto de disposición implica la eliminación directa del bien del patrimonio de su propietario, así como aquellos negocios jurídicos, como la hipoteca, que llevan consigo posibilidades de que el bien en cuestión desaparezca de dicho patrimonio, por la ejecución en caso de impago de la deuda garantizada con el derecho real» (STS 6 marzo 2015 [RJ IIO4]).

Un supuesto diferente es el piso de soltero, hipotecado con anterioridad al matrimonio, que acaba siendo después vivienda común; el destino familiar en este caso sobreviene con posterioridad al acto de gravamen. Por tanto, «difícilmente podía ser de aplicación el art. I320 CC y la doctrina de la Sala sobre el mismo, antes expuesta, en un momento en que no existe matrimonio, ni siquiera convivencia, y en el que, por tanto, no constituye vivienda familiar. Aquí el consentimiento de la esposa no puede exigirse para la constitución de la hipoteca por tales circunstancias, y tal consentimiento se desplaza al acto de aceptar que ocupen tras el matrimonio, como vivienda familiar el bien privativo del marido que éste trae al mismo con tal naturaleza pero gravado con hipoteca» (STS 6 marzo 20I5 [RJ IIO4]). Del mismo modo, es posible desafectar el bien, p. ej. merced al traslado de la residencia habitual, permaneciendo la antigua vivienda como residencia de temporada o finca de recreo $^{4^{8}}$ antes del gravamen o la enajenación, en cuyo caso habrá resultado aplicable al cambio de domicilio lo establecido en el art. I84 CDFA.

\section{II.3. Consentimientos previos y renuncias anticipadas}

Para la prestación del asentimiento requerido en el art. I90.I CDFA buena parte de la doctrina exige que su otorgamiento sea prácticamente simultáneo a la enajenación o gravamen, a fin de que el cónyuge no titular sea perfectamente conocedor de las circunstancias que rodean a tal acto dispositivo y su consentimiento esté adecuadamente informado al emitir dicha declaración de voluntad ${ }^{49}$. Lo recogía expresamente el art. I6.I de la Ley 10/2007, de 20 de marzo, de régimen económico matrimonial valenciano antes de ser declarada inconstitucional (STC 28 abril 20I6 [RTC 82]): «el consentimiento del cónyuge no titular se ha de prestar con conocimiento de los elementos esenciales y de las circunstancias accidentales del concreto negocio dispositivo». Debe tratarse de un asentimiento específico, que no cabe entender subsumido en un consentimiento general ${ }^{50}$,

${ }^{47}$ Cfr. con carácter general, LeRma, C., Actas, op. cit., pág. I50; vigente la Comp., RAMS, J., Comentarios, I993, op. cit., pág. 269 .

$4^{8}$ Vid. LaCRUZ, J.L., Derecho de familia, I982, op. cit., pág. 300.

49 Vid. García Cantero, G., «Notas sobre el régimen...», loc. cit., pág. 309; Ávila Álvarez, P., «Inscripción de bienes de ausentes, de los cónyuges y de la sociedad conyugal», RCDI, vol. 555, I983, pág. 28I. Para Aragón, SÁnChez Rubio, A., Actas, op. cit., pág. 57.

so Cfr. Álvarez-Sala Walther, J., «Aspectos imperativos en la nueva organización económica del matrimonio y márgenes a la libertad de estipulación capitular», RDN, n. II2, I98I, pág. I9; GARRIDO CERDÁ, E., «Derechos de un cónyuge sobre los bienes de otro», AAMN, t. XXV, I983, pág. I62; ElorriaGA DE Bonis, F., «La protección de la vivienda del matrimonio. Antecedentes y comentarios de la Ley 55 del Fuero Nuevo de Navarra», RJN, vol. I4, I992, pág. I90; GARCÍA DE BLAS VALENTín-FERNÁNDEZ, M.L., La vivienda familiar en situaciones de normalidad $y$ de crisis, El patrimonio familiar, profesional $y$ empresarial. t. II, Patrimonios personales, familiares, sucesorios $y$ profesionales, Bosch, Barcelona, 2005, pág. 228. 
sino que se realice con referencia a cada acto dispositivo en particular ${ }^{5 \mathrm{~T}}$; tampoco cabría deducirlo, entonces, de una renuncia genérica y anticipada al derecho expectante de viudedad en virtud del art. 274.2 CDFA.

El carácter imperativo del art. I90 CDFA aparece señalado en el art. I85.2 CDFA, frente a las dudas que podría suscitar hoy un Derecho como el CC, donde no se hace constar expresamente tal circunstancia. No obstante, la corriente de pensamiento dominante sigue considerando el art. I320 CC como norma de ius cogens $s^{52}$ aunque cada vez cobra más fuerza, siguiendo a PARRA LUCÁN, la idea de que es posible postular otras soluciones $^{53}$ ( $\nu$. gr. el Derecho balear no recoge norma equivalente) ${ }^{54}$. Tales consideraciones mueven a los autores a excluir una renuncia anticipada ${ }^{55}$, lógicamente también en Aragón ${ }^{56}$, pero no la posibilidad de un consentimiento previo ni con absoluta certeza las autorizaciones genéricas anticipadas, pues en igual modo se está dando cumplimiento al art. I90 CDFA. «El carácter imperativo del art. I320 - art. I90 CDFA- no es tampoco obstáculo a que pueda otorgarse de forma preventiva siempre que haya certeza de que tal consentimiento se proyecta sobre los actos de disposición de la vivienda habitual» ${ }^{57}$.

Si bien es cierto que cabría mayor defensa de esta tesis sobre el art. I320 CC, opino que para la total eliminación de dicha posibilidad en el CDFA sería precisa una disposición expresa en tal sentido ( $v$. gr. similar al art. 23I-9 CCCat.). Es dable pensar, igualmente, en un consentimiento previo y recíproco, p. ej. en capítulos matrimoniales, dada la mutabilidad del carácter familiar de la vivienda; con mayor razón, si en el momento de su otorgamiento ambos cónyuges son propietarios de varios inmuebles o el interés superior del menor desaparece al no tener descendencia o no existir hijos convivientes ${ }^{58}$.

En contra, GarCía-Granero FERnÁNDEZ, J., Comentarios, I990, op. cit. pág. 20I; vid. además la STS 8 junio I993 (Roj: STS I7762/I993): en los capítulos donde se muta el régimen económico, y se atribuye la propiedad del inmueble a la esposa, autoriza ésta a su marido para que pueda disponer de ella, pese a constituir la vivienda habitual de la familia. En el curso del pleito, no se logra acreditar, sin embargo, tal carácter. RDGRN I7 diciembre I987 (RJ 9718): en este caso, el apoderado lo es un tercero; si se le confieren facultades para poder vender, también para realizar la manifestación del art. 9I.I RH.

${ }^{51}$ SÁnChez-Rubio, A., Actas, op. cit., pág. 57.

${ }^{52}$ Cfr. Álvarez-Sala, J., «Aspectos imperativos...», loc. cit., pág. i9; García Cantero, G., «Notas sobre el régimen...», loc. cit., pág. 309; DE LOS Mozos, J.L., Comentarios, I982, op. cit., pág. I28; GARCía CANTERO, G., Derecho civil español, I983, op. cit., pág. 336, con anterioridad, GARCía CANTERO, G., «El estatuto jurídico del alojamiento familiar en el Derecho español», $A D C$, I978, n. ${ }^{\circ}$, págs. 709 y ss.

${ }^{53}$ PARra LuCÁn, M.A., Autonomía, op. cit., pág. I7I; cfr. algunos argumentos en BARrio Gallardo, A., «La autonomía privada...», loc. cit., págs. I659 y ss.

${ }^{54}$ Vid. STSJ Baleares 3 septiembre I998 (Roj: STSJ BAL 778/ı998).

${ }^{55}$ García CANTero, G., «Notas sobre el régimen...», loc. cit., pág. 309; García Cantero, G., Derecho civil español, op. cit., pág. 336; SÁnchez Rubio, A., Actas, op. cit., pág. 57; PARra LuCÁn, M.A., «Autonomía de la voluntad y Derecho de familia», op. cit., pág. I7I; para el CC la defendía LACRUZ, J.L., Derecho de familia, I982, op. cit., pág. 30 I.

${ }^{56}$ Vid. Merino Hernández, J.L., Comentarios al Código Civil y Compilaciones Forales (dir. M. Albaladejo), t. XXXIII. vol. 2, Artículos 48 a 88 de la Compilación de Aragón, Madrid, Edersa, I990, pág. 48; MARTínEZ CoRTES, J., Actas, op. cit., pág. I34.

${ }^{57}$ Así, Herrero García, M.J., Comentarios, I99i, op. cit., págs. 590-59i. Cfr. también Serrano García, J.A., Manual, 2012, op. cit., pág. 300: «el consentimiento se podrá otorgar antes, de forma coetánea o después de realizarse el acto dispositivo»; «que no deja de ser extensión de la doctrina común a Aragón». Cfr. BARRIO GALLARDO, A., «La autonomía privada...», loc. cit., págs. i662 y ss.

${ }^{58}$ Vid. BARRIo GAllardo, A., «La autonomía privada...», loc. cit., págs. I685 y ss. 


\section{Régimen de impugnación de los actos}

\section{III.r. Invalidez del acto de disposición}

De producirse el quebranto de la exigencia imperativa del art. I90.I CDFA, la reacción jurídica del Ordenamiento es, según la misma norma, la «nulidad» (art. I90.2 CDFA) o «anulación» (art. I90.3 CDFA) del acto dispositivo voluntario (venta, hipoteca, arrendamiento...), que será necesario «instar judicialmente» sin que se actúe por tanto ope legis, aunque quepa defender su posible actuación extrajudicial ${ }^{59}$.

Esas características unidas al plazo cuatrianual invitan enseguida a pensar en la categoría jurídica de nulidad relativa o anulabilidad. Así lo entienden los autores aragoneses siguiendo la doctrina de Derecho común ${ }^{60}$ : «la sanción, en caso de incumplimiento, se prevé en el párrafo segundo del artículo 8 Lrem (hoy art. I90 CDFA) y es la anulabilidad del acto» ${ }^{61}$. Se trata de una solución semejante a la mantenida por la jurisprudencia en aplicación del CC (cfr. arts. I320, I322, I30I CC $)^{62}$. Y lo es en detrimento de otras posibles propuestas legislativas, como p. ej. la inoponibilidad (cfr. art. I6 LAU, arts. I9 8 y 235 $\left.\mathrm{CDFA}^{63}\right)^{64}$, apuntadas por parte de la civilística aragonesa antes de la Lrem y que han inspirado el moderno art. 235 CDFA, lex generalis, sobre este art. I90 CDFA, lex specialis cuando la vivienda tiene carácter consorcial.

Con anterioridad a la Lrem 2003, se celebraba la inexistencia en Aragón de una norma como el art. I322 CC y defendía que cuando lo preterido no era un consentimiento, sino un asentimiento, no podía operar la anulabilidad, pues repugnaba a la lógica que el supuesto pudiera reconducirse a lo que no deja de ser una especie de invalidez; la categoría adecuada habría sido la inoponibilidad del acto frente a quien no ha sido parte en él, semejante a la del art. 76 Comp. relativo al derecho expectante de viudedad ${ }^{65}$. Se estaba ante una tesis opuesta a la de los arts. I322, I30I y demás concordantes del CC, de los que hoy

${ }^{59}$ Vid. la reseña que hace de los debates en el seno de la Comisión Aragonesa, ForCADA MiRANDA, F.J., Actas, op. cit., pág. 22.

${ }^{60}$ Para el CC, «la sanción, aunque no lo diga el propio texto legal, es la anulabilidad, por integración — del art. I320 CC- con la norma del art. I322.I CC». Así, DE LOS MozOS, J.L., Comentarios, I982, op. cit., pág. I3I; LACRUZ, J.L., Derecho de familia, I982, op. cit., págs. 297 y 30I; GARCÍA CANTERO, G., «Notas sobre el régimen...», loc. cit., pág. 3ir; Delgado EcheverRíA, J., «De la nulidad de los contratos. Artículos I300 a I3I4», Comentarios del Código Civil, t. II, Madrid, Ministerio de Justicia, I99I, pág. 547; Herrero GarCía, M.J., Comentarios, I99I, op. cit., pág. 594; Delgado ECheVerRíA, J. y PARRA LuCÁN, M.A., Las nulidades de los contratos. En la teoría y en la práctica, Madrid, Dykinson, 2005, págs. 60 y I45; MARTíneZ DE AguirRe, C., Curso, op. cit., pág. 234; RAMS, J., Elementos, 20I2, op. cit., pág. I28; cfr., ElORRIAGA DE BONIS, F., «La protección de la vivienda...», loc. cit., pág. I92.

${ }^{6 r}$ Forcada Miranda, F.J., Actas, op. cit., pág. 2I; Latorre Martínez de BarojA, E., Manual, op. cit., pág. 37; Serrano García, J.A., Manual, op. cit., pág. 30I; Merino, J.L., Memento Experto, op. cit., pág. I8I; antes de la Lrem, RAMS, J., Comentarios, I993, op. cit., pág. 272.

${ }^{62}$ Cfr. STS i9 octubre I994 (Roj: STS i9054/1994); STS 22 mayo I995 (Roj: STS iII56/i995); STS I4 noviembre 2000 (Roj: STS 8276/2000); además, RDGRN 29 febrero 2000 (RJ I09I) y RDGRN 9 marzo 2000 (RJ IIOO).

${ }^{6}$ «Las enajenaciones de bienes comunes realizadas por un esposo sin asentimiento del otro no pueden ser opuestas al que no asintió (...), correspondiendo a la nulidad relativa una suerte de relativa inoponibilidad» (LACRUZ, J.L., Derecho de familia, I982, op. cit., pág. 298).

${ }^{64}$ «La sanción del art. I90.2 CDFA no es la inoponibilidad del acto» (SERRAno GARCía, J.A., Manual, op. cit., pág. 30I).

${ }^{65}$ Cfr. SÁnchez Rubio, A., Actas, op. cit., pág. 65. 
parece traer causa el art. 8 Lrem y, en consecuencia, el art. I90 CDFA. «El negocio sin asentimiento del cónyuge no es nulo o anulable, porque valdrá cuando haya cesado la "familiaridad" del bien que se enajena. Hay, más bien, una suerte de ineficacia que, evidentemente, permite al adquirente a título oneroso deshacer el trato y, en su caso, reclamar indemnización» ${ }^{66}$.

En el Derecho actual, el acto dispositivo voluntario a título oneroso es en principio válido y eficaz ${ }^{67}$, pero claudicante a expensas de su eventual impugnación o confirmación ${ }^{68}$. Cuando la disposición sea gratuita ofrece dudas el silencio del legislador. Habrá de estarse en presencia de una donación, pues herencia o legado se excluyen del ámbito de aplicación de la norma según el parecer mayoritario, a salvo quizá los pactos sucesorios con transmisión de bienes de presente. La postura más extendida es que si la vivienda es común, vigente el consorcio, el acto ya no será meramente anulable, sino nulo de pleno derecho (arts. 6.3 CC) no por aplicación del 1322.2. ${ }^{a} \mathrm{CC}$, sino de la norma foral pertinente (art. 237 CDFA) ${ }^{69}$. Todo ello por ser la donación un contrato traslativo del dominio y basarse la inoponibilidad en la validez del título e ineficacia del modo ${ }^{70}$ sin que quepa su ulterior autorización judicial (RDGRN 6 octubre I966 [RJ 505I])

Tampoco lo dice el precepto, aunque lo mismo cabe predicar, en opinión

${ }^{66}$ Así, RAMS, J., Elementos, 20I0, op. cit., pág. I30. En sentido parecido, LATORRE MARTínEZ DE BAROJA, E., Manual, op. cit., pág. 38. Para el CC, cfr. Amorós Guardiola, M., Comentarios a las reformas del Código civil, t. II, Madrid, Tecnos, I977, págs. 95I y ss.; en general, Delgado, J. y PARRA, M.A., De las nulidades, op. cit., págs. I45 y SS.; y GonZÁleZ-MENESES GARCÍA-VALdeCASAS, M., «Régimen económico matrimonial en el Código civil: una revisión crítica veinticinco años después», El nuevo Derecho de Familia: Modificaciones legislativas $y$ tendencias doctrinales (dir. J.M. NAVARRO), Thomson-Civitas, Navarra, 2006, págs. 75-76.

${ }^{67}$ El acto será válido y vinculante mientras no se ejercite la correspondiente acción (vid. STS I5 enero 2008 [Roj: STS 4/2008] y STS I5 julio I999 [Roj: STS 5I46/i999]).

${ }^{68}$ El parecer del TS es uniforme en tal sentido, vid. STS 22 diciembre I993 (Roj: STS I8034/I993); STS I diciembre I994 (Roj: STS I9240/I994); STS 22 mayo I995 (Roj: STS III56/I995); STS I5 julio I999 (Roj: STS 5I46/1999); STS II junio 200I (Roj: STS 493I/200I); STS 2 julio 2003 (Roj: STS 4620/2003); STS 29 septiembre 2006 (Roj: STS 568I/2006).

Tal es la tesis tradicional. En general, para la anulabilidad, DíEz-PicAzo, L., Fundamentos del Derecho civil patrimonial, t. I, vol. I, Tecnos, Madrid, I970, págs. 306 y 307; ClaVERía Gosálbez, L.H., La confirmación del contrato anulable, Bolonia, Publicaciones del Real Colegio de Bolonia, I977, págs. 30 y 38-39; y «La nulidad de los actos jurídicos», Homenaje al Prof. Luis Martín-Ballesteros, Institución “Fernando el Católico"-CSIC, Zaragoza, I983, pág. 515.

La doctrina moderna, siguiendo a De CASTRo y Bravo, F., El negocio jurídico, Instituto Nacional de Estudios Jurídicos, Madrid, I967, págs. 498, 499 y 508, sostiene, sin embargo, que el contrato anulable debe considerarse originariamente inválido e ineficaz (DELGADO J. y PARRA, M.A., Las nulidades, op. cit., págs. 54 y 56 ). El supuesto del art. I30 in fine es, sin embargo, un cuerpo extraño al sistema; así «puede decirse que el contrato celebrado es plenamente válido y eficaz mientras el cónyuge cuyo consentimiento se pretirió no ejercite esta acción "dirigida a invalidar" el acto de disposición voluntaria» (DELGADO J. y PARRA, M.A., Las nulidades, op. cit., pág. I46).

${ }^{69}$ Vid. núm. 22 del Preámbulo.

70 Serrano García, J.A., Manual, op. cit., pág. 379; vid., además, Merino, J.L., Manual, op. cit., pág. 203, Martínez de AguirRe, C., «Líneas básicas de la reciente legislación aragonesa en materia de Derecho de Familia», El nuevo Derecho de Familia: Modificaciones legislativas y tendencias doctrinales (Dir. J.M. NAVARRO), Navarra, Thomson-Civitas, 2006, págs. 44-45; GonZÁlEZ MENESES, M., «Régimen económico matrimonial en el Código civil...», op. cit., pág. 76.

${ }_{71}^{71}$ LaCruZ, J.L., Derecho de familia, I982, op. cit., pág. 30I; Albaladejo, M., Curso, I997, op. cit., pág. I56; Costas Rodal, L., en Bercovitz, R., Comentarios, 2009, op. cit., pág. I570. 
generalizada de la doctrina, cuando se haya solicitado, pero denegado dicha licencia supletoria (art. I90.I i.f. CDFA). Para otros autores habría sido preferible suprimir la autorización judicial «y singularizar la acción de anulabilidad, como se hace en el Derecho francés» ${ }^{72}$. La contravención del auto judicial entraña la nulidad absoluta del acto dispositivo voluntario posterior. Si rige separación o participación, la respuesta es diferente: el acto de disposición, aun a título lucrativo, es igualmente anulable ${ }^{73}$ pues precisa asentimiento (SAP Zaragoza 29 septiembre 2003 [Roj: SAP Z 2242/2003] y STS 30 septiembre I997 [Roj: STS 5779/I997]) y no consentimiento (RDGRN 25 abril 2005 [RJ 5576]; RDGRN 7 diciembre 2007 [RJ 8526]; RDGRN 5 enero 20II [RJ 3432]) como correspondería a la codisposición si fuera la vivienda común, sea bajo el consorcio conyugal (art. 237 CDFA) o en separación de bienes, por las reglas de la proindivisión ordinaria (art. 399 CC) ${ }^{74}$.

\section{III.2. Plazo y legitimación}

El plazo de cuatro años es estimado extraordinariamente largo por los autores ${ }^{75}$. Esta razón mueve a señalar como dies a quo el momento desde el que se tuvo o pudo tener razonable conocimiento de la disposición de la vivienda o de su mobiliario (art. I90.2 i.f. CDFA) excluyendo otras opciones; ciertamente la notoriedad de quien mora en ella hará difícil no apercibirse de la enajenación o del gravamen ${ }^{76}$ p. ej. porque el accipiens querrá entrar a ocupar la vivienda. Basta entonces con tener noticia de la celebración sin llegar a la consumación del contrato. Es necesario, además, un conocimiento suficiente, pues sin él cabría quizá interpretar que se ha dado asentimiento tácito o confirmación ${ }^{77}$.

La evidente inmediatez en dicho conocimiento condujo al legislador foral en un principio a separarse de la orientación del CC y establecer como dies a quo sólo tal instante (v. gr. en Italia la transcripción del contrato) ${ }^{78}$; más tarde se añadió «desde la disolución del matrimonio» invirtiendo el orden del art. I30 i.f. CC (cfr. STS I4 julio I997 [Roj: STS 5020/1997]): «cada cónyuge o sus herederos estarán legitimados para instar judicialmente la nulidad de los actos de disposición (...) en el plazo de cuatro años desde que los conoció o pudo razonablemente conocer, y, en todo caso, desde la disolución del matrimonio o la separación conyugal». Tal vez habría resultado preferible mantener la tesis originaria y

${ }^{72}$ De los Mozos, J.L., Comentarios, I982, op. cit., pág. I3I; también en Aragón, Merino HernándeZ, J.L., Comentarios, I990, op. cit., pág. 50.

${ }^{73}$ Costas Rodal, L., en Bercovitz, R. Comentarios, 2009, op. cit., pág. I567.

${ }^{74}$ De los Mozos, J.L., Comentarios, Edersa, I982, op. cit., págs. I42 y I50; Herrero García, M.J., Comentarios, op. cit., pág. 596; Rivera Hernández, en M. PASQuau, M. (dir.), Jurisprudencia civil, t. III, op. cit., pág. 2559 .

${ }^{75}$ Así, LaCRUZ, J.L., Derecho de familia, I982, op. cit., pág. 298; De los Mozos, J.L., Comentarios, I982, op. cit., pág. I3I, n. Io; LATORRE MARTínEZ DE BAROJA, E., Manual, 2007, op. cit., pág. 38. Quizá esa sensación haya animado a reducir el plazo general de prescripción en el CC en virtud de la Ley 42/2015, de 5 de octubre (BOE núm. 239, 6 octubre 20I5). No obstante, la reforma no modifica el plazo de caducidad cuatrianual del art. I3OI CC.

$7^{6}$ Vid. también, Sánchez Rubio, A., Actas, op. cit., pág. 66; Latorre Martínez de Baroja, E., Manual, op. cit., pág. 38 .

${ }^{77}$ Delgado, J. y Parra, M.A., Las nulidades, op. cit., págs. I49-150.

${ }^{78}$ LACRUZ, J.L., Derecho de familia, I982, op. cit., pág. 298. 
señalar como inicio del cómputo del plazo el día desde el que el legitimado para accionar pudo tener noticia del acto de disposición, en coherencia con el art. I969 CC, y corregir así posibles situaciones abusivas.

Si la disolución es por divorcio, es muy probable que el acto dispositivo fuera ya preludio de una crisis, hecho que explicaría la conducta malintencionada del cónyuge titular de la vivienda familiar hacia quien será en el futuro su expareja. Por ello, era aconsejable introducir como dies a quo no sólo la disolución del vínculo, sino también su relajación; así el art. I90.2 CDFA alude a la separación conyugal que el art. I30I CC no menciona ${ }^{79}$. Con buena lógica, RAMS ALBESA ha defendido que la impugnación sólo procederá cuando la sentencia de separación o divorcio o, en su caso, el convenio regulador le haya adjudicado el uso de la vivienda al cónyuge no titular y no en otros supuestos ${ }^{80}$.

Cuando la disolución es por muerte (art. 85 CC), la interpretación del CC ha llevado a veces a excluir una eventual legitimación de los sucesores a título universal del cónyuge cuya anuencia se pretirió ${ }^{8}$, entiendo que sólo si rige separación de bienes o la vivienda era privativa del cónyuge disponente. Apenas existe jurisprudencia al respecto y cuando se ha concedido acción para impugnar a los sucesores universales ha sido por tratarse de un caso de simulación absoluta o un acto dispositivo a título gratuito.

Con carácter general la legitimación activa para impugnar contratos viciados de nulidad relativa se transmite a los herederos de los legitimados ex art. $659 \mathrm{CC}^{82}$, pero el del cónyuge ex art. $\mathrm{I}_{302} \mathrm{CC}$ es un supuesto un tanto particular de anulabilidad. Una parte de la doctrina se muestra crítica con esta posibilidad (PEÑA, ÁlvAREZ OlALLA, LATORRE MARTÍNEZ DE BAROJA) ${ }^{83}$ contra la postura más extendida (LACRUZ, DE LOS MOZOS) ${ }^{84}$. «Tras el fallecimiento del progenitor que tenía atribuida la facultad de control, vía asentimiento, de las enajenaciones realizadas por el titular de la vivienda», sostiene MORALEJO IMBERNÓN que «el desamparo de los descendientes es absoluto» ${ }^{85}$.

Lo cierto es que el art. I90.2 CDFA menciona expresamente a los herederos: «cada cónyuge o sus herederos estarán legitimados para instar judicialmente la nulidad de los actos de disposición realizados por el otro sin el debido consentimiento o autorización (...)». En unos casos tales sucesores a título universal serán los propios hijos del finado, que se

${ }^{79}$ Cfr. Serrano García, J.A., Manual, op. cit., pág. 30 I.

${ }^{80}$ Rams Albesa, J., Comentarios, I993, op. cit., pág. 273. Si el asentimiento uxorio fue prestado, la esposa que lo otorgó no puede esgrimir la atribución del derecho de uso sobre la vivienda ex art. 96 CC, tras la separación, para oponerse a la entrega del bien al tercero adjudicatario en el proceso de ejecución forzosa. Vid. STS 8 octubre 2010 (RJ 7445).

${ }^{8 \mathrm{r}}$ De otra parte, resulta evidente que el cónyuge vendedor que prestó su consentimiento no puede invocar después la nulidad del contrato por este motivo. Cfr. STS 22 marzo I995 (RJ 4085).

${ }^{82}$ STS I4 diciembre i999 (Roj: STS 8033/I999).

${ }^{83}$ «Con la muerte cesa la vivienda familiar», por tanto, no estarían legitimados los herederos, sólo el cónyuge, así PEÑA, M., Derecho de Familia, I989, op. cit., pág. I72; ÁlvAREZ OlAlLA, P., Responsabilidad patrimonial en el régimen de separación de bienes, Pamplona, Aranzadi, I996, pág. 463, en Aragón, cfr. LATORRE MARTínez de BAROJA, E., Manual, op. cit., pág. 38. 128 .

${ }^{84}$ LaCRuZ, J.L., Derecho de familia, I982, op. cit., pág. 298; DE los Mozos, J.L., Comentarios, I982, op. cit., pág.

${ }^{85}$ Vid. Moralejo Imbernón, N., «Artículo i320», op. cit., pág. 9328. 
guarecían en la vivienda, quienes podrán atacar la validez del acto dispositivo en ejercicio de un derecho propio, pues siempre cabría la impugnación por el plazo que le reste a su causante $^{86}$, una vez iniciado el proceso, no en virtud de las normas aragonesas, sino de la sucesión procesal establecida en los art. I6 y ss. LEC.

Pero si los hijos no son menores o no convivían con el matrimonio, sería más dudoso que se estuviese burlando el sentido de la norma (art. I9० CDFA) que por ser prohibitiva no debe ir más allá de su finalidad. Otras veces es posible que los sucesores del cónyuge no titular no sean los propios hijos o descendientes, sino otros familiares o incluso extraños, p. ej. un amigo; no habrá entonces otro interés en conservar la vivienda que el puramente crematístico. La fórmula empleada por el art. I90.2 CDFA se antoja demasiado amplia y creo que deberá ser restringida por el juez a la vista de la salvaguardia del interés familiar. Habrá de ponderarse ese interés concurrente y se contará siempre con el plazo límite de cuatro años desde que razonablemente se pudo conocer el acto dispositivo y, en todo caso, desde la disolución del matrimonio.

\section{Protección de terceros}

\section{IV.I. Crítica general del precepto}

El art. 190.3 CDFA cierra con una norma tuitiva de la seguridad del tráfico, que se sobrepone al interés familiar, puede desnaturalizar el espíritu del precepto y merece las mismas objeciones que el art. I320.2. ${ }^{a}$ CC (GIMÉnEZ DUART, DE LOS MOZOS, DE LA CUESTA SÁenz, Tamayo Carmona, Elorriaga de Bonis, Algarra Prats...): «no procede la anulación contra los adquirentes a título oneroso y de buena fe cuando el disponente manifestó que no constituía vivienda o mobiliario familiar». En el parecer de SÁNCHEZRUBio, el art. 5I Comp. omitía la mención protectora del tercero adquirente de buena fe que el precepto paralelo del CC incluye en su segundo párrafo, y gracias a ella no era transferible a la norma foral la crítica doctrinal que ha suscitado este inciso del art. $1320^{87}$.

Si en verdad el art. I90 CDFA pretende proteger al cónyuge no titular frente a quien actúa arbitrariamente o de mala fe, bastaría entonces para esquivar esta protección con que el disponente ocultara el carácter familiar de la vivienda al enajenarla o gravarla, quedando sustraída de este modo al uso común. Poco podrá hacer después el consorte cuyo asentimiento se ha omitido frente al extraño (comprador, hipotecante, etc.) más que asistir impasible a la pérdida del uso de la vivienda familiar y, una vez abandonado su hogar, reclamar una indemnización por daños contra su consorte ${ }^{88}$. Pero rara vez prosperará la restitución in natura contra el tercero, propia de la anulabilidad del acto dispositivo (art. I303 CC y STS 27 marzo 200I [Roj: STS 25I6/200I]), a salvo de lo que se dirá acerca del

\footnotetext{
${ }^{86}$ Sobre el plazo, vid. Delgado, J. y PARRA, M.A., Las nulidades, op. cit., pág. 90.

${ }^{87}$ SÁncheZ-Rubio, A., Actas, op. cit., pág. 6I.

${ }^{88}$ Sánchez-Rubio, A., Actas, op. cit., pág. 66; Gordillo CaÑas, A., «La protección de los terceros de buena fe en la reciente reforma del Derecho de Familia», $A D C$, I982, n. ${ }^{\circ}$ 4, págs. IIII-II6o; RAms, J., Elementos, op. cit., pág. I3I; Herrero García, M.J., Comentarios, i99I, op. cit., pág. 592; Elorriaga, F., «La protección de la vivienda...», loc. cit., pág. I92; LATORRE MARTíneZ DE BAROJA, E., Manual, 2007, op. cit., pág. 38; BARRIO Gallardo, A., «La autonomía privada...», loc., cit., pág. I705.
} 
derecho expectante de viudedad.

IV.2. El art. I90.3 CDFA y la protección registral

Tal vez hubiese sido preferible omitir esta referencia y dejar operar libremente las normas generales de protección del tráfico inmobiliario (art. $34 \mathrm{LH}$ ). Creo que, en un intento de reducir la eficacia exorbitante y extralimitada del art. $1320.2^{\mathrm{a}} \mathrm{CC}$, se interpretó inicialmente que el tercero aludido en él era el hipotecario, lo que hacía superflua e inútil esta mención, decía MERINO HERNÁNDEZ, al añadir poco o nada a la protección registral ${ }^{89}$. Dicha tesis no es compartida por todos los autores ${ }^{90}$ y fue después descartada por la jurisprudencia al señalar que «el adquirente a que se refiere el párrafo segundo del art. I320 no es propiamente el tercero hipotecario sino el primer adquirente fuera del círculo conyugal por el título que sea del bien en cuestión» ${ }^{9 \mathrm{~T}}$.

La norma foral mejora el tenor del art. 1320.2. ${ }^{a}$ CC por cuanto introduce la necesidad de que la disposición sea a título oneroso. Se congracia así con la doctrina y despeja posibles dudas acerca de la operatividad de esta regla en la transmisión gratuita de viviendas. El art. I90.3 CDFA elimina, además, cualquier alusión a la falsedad o error en la declaración, que había suscitado merecidos reproches, pues es casi imposible que alguien ignore cuál es su propia vivienda familiar (LACRUZ, GIMÉNEZ DUART, GORDILLO CAÑAS, GARrido CerdÁ, Álvarez Olalla) ${ }^{92}$, bastando que dicha mención sea objetivamente inexacta para que opere el art. I90.3 CDFA. La manifestación errónea a que se refiere el art. I320.2. ${ }^{a}$ CC no puede ser la equivocada expresión del dueño, que difícilmente puede estar en un error sobre si en el piso o casa que vende vive su familia, sino en el sentido de «hacer equivocarse al adquirente» ${ }^{93}$.

Se mantiene en el art. I90.3 CDFA, como es lógico, la exigencia de buena fe en el adquirente, consistente en una ignorancia inculpable del carácter familiar del inmueble. Esta suerte de afección no siempre figurará en el Registro y es una opinión extendida entre los autores (Gordillo CAÑAS, RAmS AlBeSA, RiVERA HeRnÁNDEZ) la de que el carácter familiar de la vivienda no cuenta con una adecuada publicidad legal: «es resistente a la posibilidad de su reflejo registral» en la oficina ${ }^{94}$. No son nada infrecuentes los casos en que los cónyuges residen habitualmente en un inmueble perteneciente con carácter privativo a

${ }^{89}$ Vid. De Los Mozos, J.L., Comentarios, I982, op. cit., pág. I33; Merino Hernández, J.L., Comentarios, I990, op. cit., pág. 50.

$9^{\circ}$ Martínez de Aguirre, C., Curso, 2007, op. cit., pág. 235; Rams, J., Elementos, 20io, op. cit., pág. I3I; Moralejo Imbernón, N., «Artículo I320», op. cit., pág. 9334; vid. además, LeTE DEL Río, J.M., «La disposición de la vivienda habitual por el cónyuge titular», $A C, 2003$, núm. 4, págs. Io69-Io70.

${ }^{91}$ STS II diciembre I992 (Roj: STS 9004/1992).

${ }^{92}$ Así, LacruZ, J.L., Derecho de familia, I982, op. cit., pág. 30I; GimÉnEZ DuART, T., «El artículo I.320 del Código Civil ¿es aplicable en Cataluña?», RJC, vol. 8I, n. ${ }^{\circ}$ I, I982, pág. I94; GoRdillo CAÑAS, A., «La protección de los terceros de buena fe...», loc. cit., pág. II36; CERDÁ GimENO, J., «Las capitulaciones matrimoniales...», loc. cit., pág. Io8; Álvarez Olalla, P., Responsabilidad patrimonial, op. cit., pág. 467.

${ }^{93}$ LACRUZ, J.L., Derecho de familia, I982, op. cit., pág. 30 I.

${ }^{94}$ A. GoRdillo CAÑAs, cit. por Rams, J., Elementos, 20I0, op. cit., pág. I30. 
uno de ellos y dicha circunstancia no consta tabularmente ${ }^{95}$.

Tal circunstancia se dará a conocer en el tráfico, normalmente, a través de la propia declaración del transmitente vertida de forma expresa con ocasión del acto de disposición voluntaria. Tal vez no sea obstáculo a la validez del acto en el plano civil, en tanto que una norma carente de rango legal, quizá no pueda imponer este deber ni deparar semejante resultado $^{96}$, pero a los efectos de la inscripción registral del inmueble, el notario deberá preguntar al disponente ${ }^{97}$ y reflejar en la escritura su declaración de existir o no la afección de la vivienda al destino familiar, en virtud del art. 9I.I RH. En otro caso, p. ej. la venta, será válida y eficaz entre las partes, pero no accederá a la oficina. Hecha tal manifestación, cuando el Registro publique ya el carácter no familiar de la vivienda, entrará en juego la aplicación del art. 34 LH a favor del subadquirente que desconozca esta circunstancia.

De ordinario, como se ha tenido ocasión de comprobar, el carácter familiar de la vivienda constará en la misma escritura de p. ej. venta, usufructo, hipoteca (RDGRN I7 diciembre I987 [RJ 97I8] sin que quepa inferirla de cláusulas de estilo del tipo «libre de cargas, gravámenes y arrendamientos» (RDGRN Io noviembre ig87 [RJ 8733]). No obstante, ello no significa que el adquirente no pueda conocer la afección por otros medios (RDGRN I7 diciembre I987 [RJ 97I8]), indicios de cognoscibilidad objetiva puestos de manifiesto p. ej. al haber visitado el inmueble (STS II diciembre I992 [Roj: STS 9004/1992]). Eliminada la buena fe del tercero, aunque se haya inscrito a su favor la adquisición, podrá ser anulado el acto que sustraiga la vivienda al uso común (art. 33 LH) ${ }^{98}$.

\section{IV.3. Pervivencia del derecho expectante}

En Aragón la eficacia extralimitada que tiene el I90.3 CDFA, equiparable al art. I302.2. ${ }^{a} \mathrm{CC}$, se ve contenida por la protección adicional que comporta el derecho expectante de viudedad. Recuérdese que se extingue al mediar asentimiento o ser suplido, ante su ausencia o negativa injustificada, por el juez (art. I90.I i.f. CDFA), pero no a la inversa, cuando se enajene o grave la vivienda sin haber contado con el beneplácito del no titular. Ello lleva a pensar que en la práctica el ámbito de aplicación del art. I90 CDFA quedará reducido de forma muy considerable en certera apreciación de LATORRE MARTÍNEZ DE BAROJA $^{99}$. Mayor probabilidad habrá entonces de que la impugnación del acto de enajenación o gravamen provenga del tercer adquirente, quizá por error excusable, cuando

\footnotetext{
${ }^{95}$ RiVera Hernández, M., en PASquau, M. Jurisprudencia civil, t. III, op. cit., pág. 2554. La falta de constancia tabular hace difícil, muchas veces, que el cónyuge no titular se aperciba del embargo de la vivienda, pues sólo hay obligación de notificarle la ejecución (art. I44.5 RH) en interpretación constante de la doctrina registral (RDGRN 23 febrero 2000 [RJ I083]; RDGRN 29 febrero 2000 [RJ IO9I]; RDGRN 9 marzo 2000 [RJ IIO०]), con anterioridad a la reforma del RH de I998, vid. RDGRN I3 julio I998 [RJ 5967]. Para Aragón, cfr. en especial, Medrano SÁncheZ, J.I., «Embargo y ejecución de bienes de personas casadas en Aragón», Actas de los Decimoterceros Encuentros del Foro de Derecho Aragonés El Justicia de Aragón, 2004, pág. 82.

${ }^{96}$ Cfr. LaCRUZ, J.L., Derecho de familia, I982, op. cit., pág. 302.

${ }^{97}$ Rams, J., Comentarios, I993, op. cit., pág. 272.

${ }^{98}$ Martínez de Aguirre, C., Curso, 20i6, pág. 236; BARrio Gallardo, A., «La autonomía privada...», loc. cit., pág. I704.

${ }^{99}$ Latorre Martínez de Baroja, E., Manual, op. cit., pág. 37.
} 
se percate más adelante de la afección familiar de la vivienda, tras la ocultación de este carácter por el cónyuge titular, so pena de ver su adquisición gravada con un usufructo al fallecer el tradens.

IV.4. La disposición del mobiliario y los terceros

El art. $1320.2^{a}$ se encuentra circunscrito a la protección de la familia respecto a la disposición voluntaria de la vivienda; no así de su mobiliario, sobre el que la norma del CC guarda silencio y cuya aplicación por extensión analógica no es posible según el sentir de la doctrina dominante ${ }^{\mathrm{Ioo}}$. El último apartado parece una previsión dedicada a la enajenación o gravamen de inmuebles, mientras que respecto de la disposición del mobiliario de uso ordinario, enseres destinados al empleo de todo el grupo familiar, mencionados en el art. I320. $\mathrm{I}^{\mathrm{a}} \mathrm{CC}$, el precepto debe ser integrado con la correspondiente regla de protección del tráfico mobiliario $^{\text {ror }}$. Se ha de acudir, por tanto, al art. $464 \mathrm{CC}$, norma tuitiva de terceros que confían en la apariencia y para los que la posesión equivale al título. El precepto foral, por el contrario, sí recoge tal mención («no procede la anulación (...) cuando el disponente manifestó que no constituía (...) mobiliario familiar») y salva los problemas de la interpretación extensiva que la doctrina había señalado a propósito del art. I320 CC al establecer un régimen común para la vivienda y sus enseres.

\section{Bibliografía}

Albaladejo, M., Curso de Derecho Civil, t. IV, Barcelona, Bosch, I997.

Álvarez Olalla, P., Responsabilidad patrimonial en el régimen de separación de bienes, Pamplona, Aranzadi, I996.

ÁlvareZ-Sala Walther, J., «Aspectos imperativos en la nueva organización económica del matrimonio y márgenes a la libertad de estipulación capitular», Revista de Derecho Notarial (RDN), n. ${ }^{\circ}$ II2, I98I, págs. 7-57.

Amorós Guardiola, M., «De las capitulaciones matrimoniales. Artículos 1325-1335», Comentarios a las Reformas del Derecho de Familia, t. II, Madrid, Tecnos, I984, págs. I515-1569.

AmunÁtegui Rodríguez, C., «La libertad de pacto en el régimen de separación de bienes», Autonomía de la voluntad y negocios jurídicos de la familia (coord. J. Rams), Madrid, Dykinson, 20IO, págs. II7-272.

Ávila Álvarez, P., «Inscripción de bienes de ausentes, de los cónyuges y de la sociedad conyugal», Revista Crítica de Derecho Inmobiliario, vol. 555, I983, págs. 273-312.

BANDRÉS SÁnCheZ-CruZAT, J.M. y R.M., «Gestión de los bienes privativos. Art. 5I». Comentarios al Código Civil y Compilaciones Forales (dir. M. Albaladejo), t. XXXIII, vol. $2^{\circ}$. Artículos 48 a 88 de la Compilación de Aragón, Madrid, Edersa, I990, págs. 40-50.

Barrio Gallardo, A., «La autonomía privada y el art. 1320 del Código civil», Anuario de Derecho Civil (ADC), 2012, n. ${ }^{\circ}$ 4, págs. I653-1744.

${ }^{100}$ LACRUZ, J.L., Derecho de familia, op. cit., pág. 207; MARTínEZ De Aguirre, C., Curso, 20i6, op. cit., pág. 235; SÁnchez-Rubio, A., Actas, op. cit., pág. 6i; en contra, defendiendo la extensión analógica del I320.2. ${ }^{a}$ CC, homólogo del art. I90.3 CDFA, Albaladejo, M., Curso, I997, op. cit., pág. 1568.

Ior BANDRÉs SÁNCHEZ-CruZAT, J.M. y R.M., Comentarios, I990, op. cit., pág. 50; vid. también en el régimen del CC, LACRUZ, J.L., La reforma del Derecho de familia..., op. cit., pág. I32; DE Los Mozos, J.L., Comentarios, I982, op. cit., pág. I32; GoRdillo CAÑAS, A., La protección del adquirente..., op. cit. pág. II38. 
BAyod López, C., «La viudedad», Manual de Derecho civil aragonés (dir. J. Delgado Echeverría, coord. M.A. Parra Lucán), Zaragoza, El Justicia de Aragón, 20I2, págs. 457-495.

— «Artículo igo. Vivienda familiar», Código del Derecho Foral de Aragón. Concordancias, doctrina y jurisprudencia (dir. J. Delgado, coord. M.C. Bayod y J.A. Serrano), Zaragoza, Gobierno de Aragón, 2015, págs. 347-348.

Belda SÁenz, M.C., «Notas para un estudio del artículo I320 del Código civil español», Revista de Derecho Privado (RDP), abr. 1985, págs. 331-348.

Cano Tello, C.A., La nueva regulación de la sociedad de gananciales, Madrid, Cuadernos Civitas, I98I.

Cerdá Gimeno, J., «Las capitulaciones matrimoniales en la reforma de I98I», Documentación Jurídica (DJ), t. I, Madrid, Ministerio de Justicia, ene-dic. I982, págs. 23I y ss.

Clavería GosálBez, L.H., La confirmación del contrato anulable, Bolonia, Publicaciones del Real Colegio de Bolonia, I977.

Costas Rodal, L., «Del régimen económico matrimonial. Disposiciones generales», Comentarios al Código civil (coord. R. Bercovitz), Cizur Menor (Navarra), Thomson Reuters-Aranzadi, 2009, págs. I559-I573.

De Castro y Bravo, F., El negocio jurídico, Madrid, INEJ, ig67.

De la Cámara Álvarez, M., «El nuevo artículo I4I3 del Código Civil», Anuario de Derecho Civil $(A D C)$, vol. XII, n. ${ }^{\circ}$ 2, I959, págs. 45I-479.

De los Mozos, J.L., Comentarios al Código Civil y Compilaciones Forales, t. XVIII, vol. Iº, Artículos 1315 a 1343 del Código Civil, Madrid, Edersa, I982.

Delgado ECheverRía, J., «De la nulidad de los contratos. Artículos izoo a I3I4», Comentarios del Código Civil, t. II, Madrid, Ministerio de Justicia, I99I, págs. 54I-57I.

Delgado ECheVerría, J. y PARRA LuCÁN, M.A., Las nulidades de los contratos. En la teoría y en la práctica, Madrid, Dykinson, 2005.

DíEz-PICAZO, L., Fundamentos del Derecho civil patrimonial, t. I-I, Madrid, Tecnos, I970.

ELORRIAGA DE BonIS, F., «La protección de la vivienda del matrimonio. Antecedentes y comentarios de la Ley 55 del Fuero Nuevo de Navarra», Revista Jurídica de Navarra (RJN), vol. I4, I992, págs. I77-I9O.

Espiau Espiau, S., La vivienda familiar, Barcelona, Promociones y Publicaciones Universitarias, SA (PPU), 1992.

ForCADA MiRANDA, F.J., «La vivienda familiar en las situaciones de ruptura matrimonial», Actas de los Decimocuartos Encuentros del Foro de Derecho Aragonés, Zaragoza, El Justicia de Aragón, 2005, págs. 7-76.

García CANTERo, G., «El estatuto jurídico del alojamiento familiar en el Derecho español», Anuario de Derecho Civil (ADC), 1978, n. ${ }^{\circ}$ 4, págs. 709-728.

— «Notas sobre el régimen matrimonial primario», Documentación Jurídica (DJ), ene-dic. I982, págs. 299-3I2.

— «El régimen matrimonial primario y su marco en el Código civil», Revista Jurídica de les Illes Balears (RJIB), n. ${ }^{\circ}$ I4, 2016 , págs. 9-29.

García de Blas VAlentín-FernÁNDEZ, M.L., La vivienda familiar en situaciones de normalidad y de crisis, El patrimonio familiar, profesional y empresarial. Sus protocolos (coord. M. Garrido y J.M. Fugardo), t. II, Patrimonios personales, familiares, sucesorios y profesionales, Barcelona, Bosch, 2005, págs. $195-266$.

García-Granero Fernández, J., Comentarios al Código Civil y Compilaciones Forales (dir. M. Albaladejo), t. XXXVI, vol. I ${ }^{\circ}$, Madrid, Edersa, I990.

GaRrido Cerdá, E., «Derechos de un cónyuge sobre los bienes de otro», Anales de la Academia Matritense del Notariado (AAMN), t. XXV, I983, págs. I43-176.

GIMÉNEZ DUART, T., «La organización económica del matrimonio tras la reforma de 13 de mayo de I98I», Revista de Derecho Notarial (RDN), jul-dic. I98I, págs. 73-I22. 
— «El artículo I320 del Código Civil ¿es aplicable en Cataluña?», Revista Jurídica de Cataluña (RJC), vol. 8I, n. ${ }^{\circ}$ I, I982, págs. I93-210.

GonZÁLEZ-Meneses GarCíA-VALDECASAS, M., «Régimen económico matrimonial en el Código civil: una revisión crítica veinticinco años después», El nuevo Derecho de Familia: Modificaciones legislativas y tendencias doctrinales (dir. J.M. Navarro), Navarra, Thomson-Civitas, 2006, págs. 49-78.

Gordillo CAÑAS, A., «La protección de los terceros de buena fe en la reciente reforma del Derecho de Familia», Anuario de Derecho Civil (ADC), I982, n. ${ }^{\circ}$ 4, págs. IIII-II6o.

Herrero García, M.J., «Del régimen económico del matrimonio. Disposiciones Generales», Comentario del Código Civil, t. II, Madrid, Ministerio de Justicia, págs. 57I-602.

Lacruz Berdejo, J.L. y Sancho Rebullida, F.A., Derecho de Familia, Fasc. ${ }^{\circ}, 2^{\circ}$ y $3^{\circ}$, edición experimental, Bosch, Barcelona, I982.

Latorre Martínez de Baroja, E., «Disposiciones generales», Manual de Derecho matrimonial aragonés (dir. J.L. Merino Hernández), Zaragoza, Los Fueros, 2007, págs. I7-5I.

LeRma Rodrigo, C., «El derecho expectante de viudedad», Actas de los XIV Encuentros del Foro de Derecho Aragonés, Zaragoza, El Justicia de Aragón, 2005, págs. I47-I53.

LETE DEL Río, J.M., «La disposición de la vivienda habitual por el cónyuge titular», Actualidad Civil $(A C), 2003$, n. $^{\circ}$, págs. 1055-1072.

Martínez Cortés, J., LaCruz Mantecón, M. y Soro Domingo, L., «El régimen económico matrimonial de separación de bienes», Actas de los Decimoterceros Encuentros del Foro de Derecho Aragonés, Zaragoza, El Justicia de Aragón, 2004, págs. 89-I43.

MARTÍNEZ DE AGUiRRe, C., «Líneas básicas de la reciente legislación aragonesa en materia de Derecho de Familia», El nuevo Derecho de Familia: Modificaciones legislativas y tendencias doctrinales (dir. J. M. Navarro), Navarra, Thomson-Civitas, 2006, págs. 27-48.

Martínez de Aguirre Aldaz, C. (coord.), De Pablo Contreras, P. y Pérez Álvarez, M.A., Curso de Derecho Civil (IV), Derecho de Familia, Madrid, Edisofer, 2016.

MEDRANo SÁnCHEZ, J.I., «Embargo y ejecución de bienes de personas casadas en Aragón», Actas de los Decimoterceros Encuentros del Foro de Derecho Aragonés, Zaragoza, El Justicia de Aragón, 2004, págs. 5-83.

Merino Hernández, J.L., Comentarios al Código Civil y Compilaciones Forales (dir. M. Albaladejo), t. XXXIII, vol. 2, Artículos 48 a 88 de la Compilación de Aragón, Madrid, Edersa, I990.

- (dir.). Memento Experto. Derecho Foral de Aragón, Francis Lefebvre, $201 \mathrm{I}$.

Moralejo Imbernón, N., «Artículo I320», Comentarios al Código Civil (dir. R. Bercovitz), t. VII. Arts. 1265 a 1484, Valencia, Tirant lo Blanch, 2013, págs. 9327-9335.

ORTEGA y DíAZ-AmbronA, J.O., «Constitución y derecho constitucional», El hogar y el ajuar de la familia en las crisis matrimoniales: bases conceptuales y criterios judiciales (dir. P.J. Viladrich), Pamplona, Eunsa, i986, págs. 35-60.

PARra LuCÁn, M.A., «El contrato de arrendamiento de vivienda: desde la salvaguardia de los derechos del arrendatario a su desprotección», Cuadernos de Aranzadi Civil-Mercantil, El Cano (Navarra), Thomson-Aranzadi, 2014.

— «Autonomía de la voluntad y Derecho de familia», Autonomía de la voluntad en el Derecho privado: Estudios en conmemoración del 150 aniversario de la Ley del Notariado (coord. L. Prats Albentosa). t. I. Derecho de la persona, familia y sucesiones, Madrid, Wolters Kluwer España-Consejo General del Notariado, 2012, págs. 97-454.

Peña Bernaldo De Quirós, M., Derecho de Familia, Madrid, Universidad Complutense de Madrid, Sección de Publicaciones, 1989.

Rams Albesa, J., «Comentario de los arts. 4I a 59 de la Compilación (Pasivo, gestión, disolución, liquidación y división de la comunidad conyugal legal)», Comentarios a la Compilación del Derecho civil de Aragón (dir. J. Delgado), vol. II, Zaragoza, DGA, I993, págs. 97-213 y 22I-380.

- Elementos de Derecho civil, t. IV. Derecho de familia, Madrid, Dykinson, 2010. 
Rebolledo VARELA, A.L., «La vivienda familiar y la Ley de Arrendamientos Urbanos», La Ley, I984, n. ${ }^{\circ}$ 2, págs. 503-509.

Rivera HeRnÁNDEZ, M., «Del régimen económico matrimonial. Disposiciones generales», Jurisprudencia civil comentada. Código civil (dir. M. Pasquau), t. III, Granada, Comares, 2009, págs. 2513-2570.

RODRÍGUEZ LóPEZ, F., «Notas sobre la vivienda habitual de la familia (en turno de rectificación)», Revista Crítica de Derecho Inmobiliario (RCDI), I993, págs. I599-1626.

SerRANo GarCía, J.A., «Derecho de la familia matrimonial. Efectos generales del matrimonio», Manual de Derecho civil aragonés (dir. J. Delgado Echeverría, coord. M.A. Parra Lucán), Zaragoza, El Justicia de Aragón, 20I2, págs. 28I-309. 